\title{
IMPROVE PRODUCTIVITY IN A BEARING INDUSTRY USING VALUE STREAM COSTING
}

\author{
DOI: 10.17261/Pressacademia.2020.1360 \\ PAP- V.12-2020(24)-p.89
}

\section{Mahmoud Al-Odeh}

Bemidji State University, Bemidji , MN, United States of America.

Mahmoud.Al-Odeh@bemidjistate.edu, ORCID: 0000-0002-2602-927X

To cite this document

Al-Odeh, M. (2020). Improve productivity in a bearing industry using value stream costing. PressAcademia Procedia (PAP), V.12, p.89.

Permanent link to this document: http://doi.org/10.17261/Pressacademia.2020.1360

Copyright: Published by PressAcademia and limited licensed re-use rights only.

\begin{abstract}
Purpose- This research aims to apply the technique of Value Stream Costing (VSC) in an industrial manufacturing company. Lean manufacturing technique is used to minimize the waste and maximize the flow. Value stream mapping (VSM) can identify continued opportunities to enhance value, eliminate waste, and improving flow. Four steps is followed in order to fulfil the value stream mapping: identifying the product, creating a current state value stream map, creating a future state value stream map, and creating an action plan. After developing the current and future state value maps, VSC is used to evaluate the improvements that are gained by implementing VSM technique. Parameters such as productive and non-productive capacity, takt time, production lead time (PLT), and process cycle efficiency (PCE) will be used to evaluate the current and future state value stream maps and to conduct the VSC analysis. Graphs will be used to show the improvements and demonstrate some of the ideas.

Methodology- The study employs Lean manufacturing (LM) methodology to improve the overall organizations' performance. In specific, Value stream mapping (VSM) analysis is used in this research. VSC is one tool that can be used for implementing the lean manufacturing technique. Value Stream Costing (VSC) is a new technique that can be used to evaluate the efficiency of lean implementation and to calculate the percentage of cost reduction. Observing the process is also used to collect data before and after the improvement implementations. Findings- The analysis reveals that Value stream mapping (VSM) is helpful to implement improvement and it is used to look at the improvement from financial perspective. Implementing the value stream costing resulted in improving the capacity from $8 \%$ to $23 \%$. It also helped the company to reduce the total cost for the product from $\$ 8,706.78$ to $\$ 7,623.5$.

Conclusion- Based on the analysis and the findings, it may be concluded that VSC is a technique that should replace the traditional costing technique. VSC analysis is emphasising on added a value to products and services by removing costs related to non-value added activities. This technique is in support with lean techniques goals of reducing waste and improving productivity. The gains from implementing lean can be translated into dollar amount using VSC to support future improvement activities.
\end{abstract}

Keywords: Value stream costing, productivity, case study, cost analysis, bearing manufacturing JEL Codes: M20, L60, C83

\section{REFERENCES}

Al-Odeh, M. (2018). Return on Investment for Continuous Improvement Activities, The Association of Technology, Management, and Applied Engineering (ATMAE), Kansas City, Missouri

Al-Odeh M. (2016). Implementing Value Stream Costing Analysis to Support Lean Management \& Process Improvement, The Association of Technology, Management, and Applied Engineering (ATMAE), Orlando, Fl.

Ofileanu D. (2015). Value Stream Cost Analysis In The Romanian Footwear Industry

Maskell, B.; Baggaley, B.; Grasso, L. (2012). Practical Lean Accounting, Second Edition, CRC Press, New York, page 159 